Article

\title{
Soil Organic Carbon Shapes AMF Communities in Soils and Roots of Cynodon dactylon under Anti-Seasonal Drying-Wetting Cycles
}

\author{
Xie Luo ${ }^{1,2}$, Xinhua He ${ }^{1,3, * \mathbb{D}}$, Xiumei Luo ${ }^{4}$, Yining Liu ${ }^{1}$, Junqi Wang ${ }^{2}$ and Jinyan Dong ${ }^{2, *}$ \\ 1 Centre of Excellence for Soil Biology, School of Resource and Environment, Southwest University, \\ Chongqing 400715, China; rolexluo@sina.com (X.L.); lyningdian@163.com (Y.L.) \\ 2 Key Laboratory of Eco-environments in Three Gorges Reservoir Region (Ministry of Education), \\ School of Life Science, Southwest University, Chongqing 400715, China; wangjunqi314@163.com \\ 3 School of Biological Sciences, University of Western Australia, Perth 6009, Australia \\ 4 School of Life Science, Chongqing University, Chongqing 401331, China; luoxm@cqu.edu.cn \\ * Correspondence: xinhua.he@uwa.edu.au (X.H.); donjyaa@swu.edu.cn (J.D.)
}

Received: 20 August 2019; Accepted: 11 October 2019; Published: 17 October 2019

\begin{abstract}
Anti-seasonal drying-wetting cycles since 2010 have substantially altered its soil and vegetation status in the drawdown zone of China's Three Gorges Reservoir (TGR). Such alternations may thus affect the composition and functioning of soil microbial communities, including the beneficial arbuscular mycorrhizal fungi (AMF), which enhance plant performance. Moreover, limited information is available if AMF communities are different in soils and roots, particularly under contrasting land-use changes. By combining the Illumina Miseq sequencing with bioinformatics analyses, AMF communities in both rhizosphere soils and roots of a stoloniferous and rhizomatous $\mathrm{C}_{4}$ perennial of Cynodon dactylon were characterized under three land-use types: (1) crop cultivated, (2) non-cultivated non-disturbed, and (3) disturbed non-cultivated land. A total of 35 and $26 \mathrm{AMF}$ taxa were respectively detected from $C$. dactylon rhizosphere soils and roots from these three land-use types, which had endured four anti-seasonal drying/summer-wetting/winter cycles. Contrasting differentiations in the AMF community composition and structure were displayed in the C. dactylon rhizosphere soils and roots, and between land-use types. Nonmetric multidimensional scaling analyses revealed that AMF communities significantly correlated to soil organic carbon in the rhizosphere soils and roots of $C$. dactylon, to land-use types only in rhizosphere soils, whereas to soil moisture only in roots. Our results highlight the effects of soil nutrients and land-use changes on AMF community composition and diversity under the canopy of $C$. dactylon in TGR. The identified dominant AMF taxa can be employed to vegetation restoration in such degraded habitats globally.
\end{abstract}

Keywords: available phosphorus; $\mathrm{C}_{4}$ grass; illumina Miseq sequencing; nonmetric multidimensional scaling; soil carbon and nitrogen ratio

\section{Introduction}

The water table between $145 \mathrm{~m}$ and $175 \mathrm{~m}$ (impounded level) of the newly-formed drawdown zone has created a total area of $\sim 400 \mathrm{~km}^{2}$ water body along the Three Gorges Reservoir (TGR) since the completion of a $185 \mathrm{~m}$ high dam in the middle stream of Yangtze River in 2010 [1]. As a consequence of flood control and hydropower manipulation, a $30 \mathrm{~m}$ hydro-logically seasonal up-and-down regime has been switched down to less than $140 \mathrm{~m}$ water table by emptying the downstream water during the natural flooding (wetting) in summer, but up to $175 \mathrm{~m}$ water table by storing the water during the natural un-flooding (drying) in winter. After such a conversion of drying-wetting cycles, plant species adapted to previously terrestrial habitats have almost completely degraded or die 
out, leading to totally different soil properties [2], in the newly-formed drawdown zone in the TGR region. Vegetation restoration, either structurally [3] or functionally [4], has thus been practiced to tackle with these changes in this drawdown zone [5-7]. Accumulated evidences have showed that Cynodon dactylon (a perennial, stoloniferous, and rhizomatous $\mathrm{C}_{4}$ species) is one of the promising restoration candidates $[8,9]$. This plant species can rapidly spread with creeping rhizomes, culms, and stolons, which adapt to altered drying-wetting conditions [8,9]. After revegetation, C. dactylon has experienced the hydrological manipulation of the drawdown zone, and contributed leaves and litter detritus, either in fresh or decomposable status, into the riparian soil. Soil microorganisms could thus play a vital role in nutrients cycling and soil fertility during the revegetation process in the TGR. However, limited information is available regarding how soil microbial communities could respond to such anti-seasonal drying-wetting cycles.

Studies have shown that interplays between below- and above-ground biotic communities play fundamental roles in controlling ecosystem processes and properties $[10,11]$. This is particularly true for arbuscular mycorrhizal fungi (AMF), which are essential components of plant-soil systems due to their symbiotic associations with the majority of host plants [12]. In general, AMF benefits their host plants with the increased acquisition of poorly mobile soil nutrients, especially phosphorus (P) and potassium (K) [12], enhanced stress tolerance, and stability of ecosystems [13-15]. Thus, AMF should have received much attention in the indigenous seedling production and restoration [16]. Meanwhile, the biological consequence of plant-AMF interactions is complicated, since the temporal and spatial heterogeneity varies with land-use changes $[17,18]$. The conversion from natural habitats into agricultural lands has resulted in vegetation loss, soil degradation, and negative influences on nutrient biogeochemical cycles [19]. Such changes in the vegetation cover and soil characteristics have been one of the leading causes for the loss of plant biodiversity $[1,18,20]$. In cultivated farm lands, AMF population, taxa composition, and diversity tend to be decreased when compared with their natural ecosystems $[18,21,22]$. Conversely, AMF diversity in the cultivated lands is higher than that in the natural land soils in a hot and arid ecosystem [17]. As a result, further studies are needed to understand how AM diversity and community vary with land-use change.

In addition to the crop cultivated land (CL), two newly-formed land-use types, as non-cultivated non-disturbed land (NCND) and disturbed non-cultivated land (DNC), have existed along the drawdown zone of the TGR's riparian banks after the completion of the hydropower dam since 2010. The disturbances in DNC include frequent human activities, e.g., boat-transportation, fishing, etc. during the flooding wet period (between October and March), while picnicing, fishing, etc. during the non-flooding dry period (between April and September). The CL is tilled by manpower with low-input management, and peanut (Arachis hypogaea Linn.) is commonly cultivated during the non-flooding period. Interestingly, the population of the stoloniferous and rhizomatous C. dactylon, a widely distributed flooding-tolerant $C_{4}$ that is perennial in the drawdown zone of the TGR, has increased under the prolonged submergence and drying-wetting cycles since 2010 [23]. Apart from a strong growth performance, C. dactylon has shown high AMF colonization $(15-54 \%)$ [23], which might contribute to improved vegetation restoration in the anti-seasonal drawdown zones of TGR [24]. Although the diversity and distribution patterns of AMF communities have been investigated in TGR [24] and wetlands [25-29], the responses of the AMF community of flooding-tolerant plants, including $C$. dactylon, to changes in soil property and land-use types under the drying-wetting alternations are still poorly understood. Moreover, limited information is available if AMF occurrence and functioning are different between soils and roots, particularly under contrasting land-use changes $[24,26]$. Therefore, we focused on the AMF community structure and diversity in the rhizosphere soils with those in the roots of $C$. dactylon under three contrasting land-use types of (1) NCND, (2) DNC, and (3) CL along the drawdown zone of the riparian banks in the TGR. Specifically, we hypothesized that (i) AMF communities were different in the rhizosphere soil and roots of $C$. dactylon; (ii) Both of the AMF communities and diversity in the rhizosphere soils/roots of $C$. dactylon were differentially affected by land-use type; and, (iii) The responses of $C$. dactylon 
rhizosphere soils/roots AMF communities to soil organic carbon and available phosphorus were different under contrasting land-use changes.

\section{Materials and Methods}

\subsection{Site Description and Sampling}

The drawdown zone of the TGR region $\left(29^{\circ} 16^{\prime}-31^{\circ} 25^{\prime} \mathrm{N}, 106^{\circ} 50^{\prime} \mathrm{E}-111^{\circ} 50^{\prime} \mathrm{E}\right)$ is located along a $600 \mathrm{~km}$ long valley between Chongqing $\left(29^{\circ} 16^{\prime} \mathrm{N}, 116^{\circ} 50^{\prime} \mathrm{E}\right)$ and Yichang $\left(31^{\circ} 25^{\prime} \mathrm{N}, 111^{\circ} 50^{\prime} \mathrm{E}\right)$ in the middle stream of the Yangtze River in China. The climate of this region is a southeast subtropical monsoon with a mean annual temperature of $19{ }^{\circ} \mathrm{C}$, which ranges from $7.8^{\circ} \mathrm{C}$ in February to $26.2^{\circ} \mathrm{C}$ in August. The mean annual rainfall is about $1304 \mathrm{~mm}$ (80\% in February and October) (Figure S2) [30]. The soil was clay loam (Entisol, USDA soil taxonomy).

Since 2010, the water table has been regulated to $175 \mathrm{~m}$ in winter and $145 \mathrm{~m}$ in summer in the TGR's dam for the purpose of flood control and hydropower manipulation. In May, the water table gradually descends and C. dactylon starts to grow in the drawdown zone, thus it is not a good time to collect soil and root samples in May or June. In early September 2014, after five months growth, the roots and rhizosphere soils of $C$. dactylon were then sampled in the drawdown zone between $145 \mathrm{~m}$ and $175 \mathrm{~m}$ before the water table was rising in October. The distance between the sampling sites of $\mathrm{A}$ and $\mathrm{B}$ or $\mathrm{B}$ and $C\left(1050 \mathrm{~m}^{2}\right.$, each) was about $130 \mathrm{~km}$ along the drawdown zone in the TGR (Figure 1a and Table S1). All land-use types of NCND, DNC, and CL, also the $C$. dactylon vegetation, were included in the A, B, and $C$ site (Figure $1 b$ ). In each land-use type site, $C$. dactylon plants with a similar growing period were selected for root sampling. Each site had three blocks and each block had three sampling plots $\left(10 \mathrm{~m}^{2}\right)$. In each sampling plot, five groups (three plants each) of $C$. dactylon were extracted with almost all roots (Figure $1 b$ ). Root-attached soils from $C$. dactylon were gently shaken by holding with their shoots and brushed down as rhizosphere soils. Those rhizosphere soils or roots from one plot were mixed as one composite sample. A total of five composited rhizosphere soils and five composited root samples were thus obtained from each land-use type. However, the root sample from the same land-use type land in site A, B, or C was mixed together for later DNA extraction. Plant roots, stems, and leaves were also harvested. All samplings were randomly performed, as shown in Figure 1b. The rhizosphere soil and root samples were stored in plastic bags at $4{ }^{\circ} \mathrm{C}$ until processed. After the debris removal, soil samples were passed through a $2 \mathrm{~mm}$ sieve, homogenized, and divided into two parts. One part of the soils was kept at $-80^{\circ} \mathrm{C}$ for molecular analysis and another part was air-dried for the analysis of soil physicochemical properties. One part of the fresh roots was washed in running water, dried with paper towels, and stored at $-80^{\circ} \mathrm{C}$ for molecular analyses. Another part of the fresh roots was stored in the FAA solution ( $5 \mathrm{~mL}$ formaldehyde, $5 \mathrm{~mL}$ acetic acid, and $90 \mathrm{~mL} \mathrm{50 \%} \mathrm{ethanol)} \mathrm{for} \mathrm{the} \mathrm{root} \mathrm{AMF}$ colonization assessment.

(a)

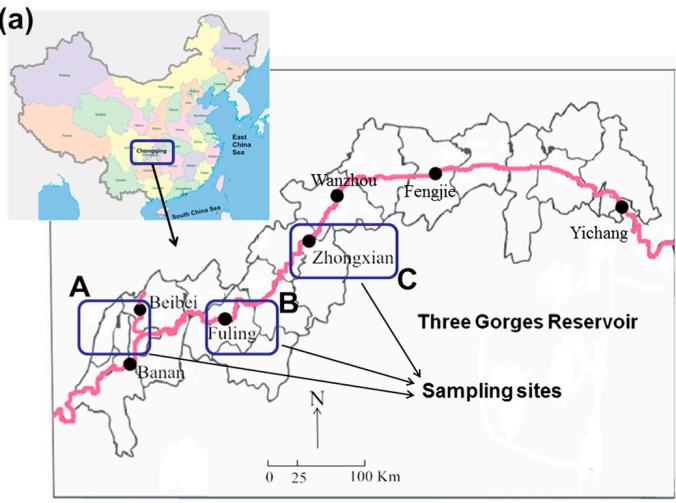

(b)

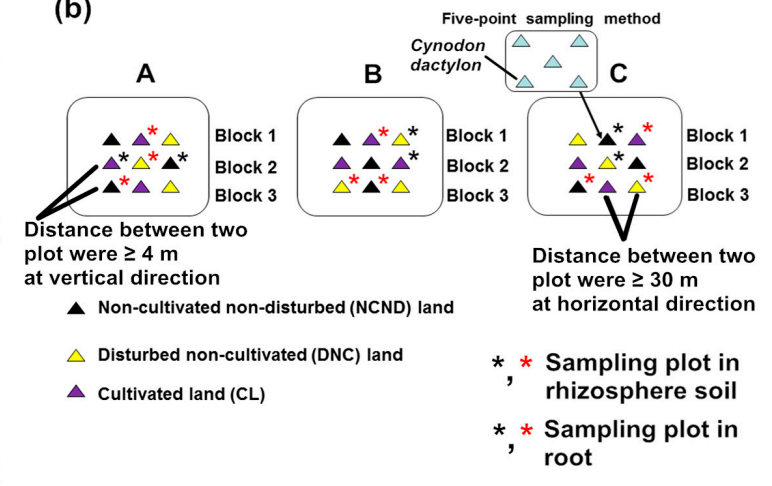

Figure 1. Geographical locations of study sites (a) and sampling patterns of both roots and soils in three contrasting land use types $(\mathbf{b})$ along the drawdown zone of Three Gorges Reservoir. 


\subsection{Soil Physical and Chemical Properties}

Soil $\mathrm{pH}$ (soil: water $=1: 2.5, v / v$ ) was measured with a digital $\mathrm{pH}$ meter (Sartorius $\mathrm{pH}$ Meter PB-21, Beijing, China). Soil organic carbon (SOC) was determined by the $\mathrm{K}_{2} \mathrm{Cr}_{2} \mathrm{O}_{7}$ oxidation method. Soil total nitrogen (TN) was measured with the Kjeldahl digestion (Distillation Unit B-324, Büchi Company, Flawil, Switzerland). Soil available phosphorus (AP) was extracted with $0.5 \mathrm{M}$ sodium bicarbonate $\left(\mathrm{NaHCO}_{3}\right)$ at $\mathrm{pH} 8.5$ and was evaluated while using the Olsen method through colorimetrical analyses (UV-1800, AOE Instruments, Shanghai, China). Soil available potassium (AK) was extracted with $1 \mathrm{M}$ ammonium acetate $\left(\mathrm{NH}_{4} \mathrm{Ac}\right)$ at $\mathrm{pH} 7$ and then measured using flame atomic adsorption spectrophotometry (AP1200, Aopu Instruments, Shanghai, China). Soil moisture (SM) was measured after $24 \mathrm{~h}$ oven-drying at $105^{\circ} \mathrm{C}$. The determination of all the above-mentioned measurements was according to [31]. Soil electrical conductivity (EC) was measured according to the saturated soil paste extract method [32]. Table 1 presens the basic physical and chemical properties of rhizospheres soils.

Table 1. Chemical properties of rhizosphere soil in three contrasting land use types along the drawdown zone of the Three Gorges Reservoir.

\begin{tabular}{|c|c|c|c|c|c|c|c|c|}
\hline Land-Use Type & EC & $\mathrm{pH}$ & SM (\%) & SOC $(\mathrm{g} / \mathrm{kg})$ & TN (g/kg) & $\mathrm{C} / \mathrm{N}$ ratio & $\mathrm{AK}(\mathrm{mg} / \mathrm{kg})$ & AP $(\mathrm{mg} / \mathrm{kg})$ \\
\hline NCND & $2588 \pm 10.0 \mathrm{a}$ & $8.18 \pm 0.01 b$ & $27.58 \pm 1.17 \mathrm{a}$ & $9.50 \pm 0.02 \mathrm{a}$ & $0.69 \pm 0.01 b$ & $13.71 \pm 0.19 a$ & $119.56 \pm 1.40 \mathrm{~b}$ & $12.09 \pm 0.19 \mathrm{a}$ \\
\hline $\mathrm{DNC}$ & $2600 \pm 2.00 \mathrm{a}$ & $8.28 \pm 0.00 a$ & $16.76 \pm 2.10 b$ & $6.77 \pm 0.10 c$ & $0.59 \pm 0.01 c$ & $11.47 \pm 0.33 c$ & $40.56 \pm 0.92 c$ & $9.95 \pm 0.28 b$ \\
\hline $\mathrm{CL}$ & $2140 \pm 6.00 \mathrm{~b}$ & $8.27 \pm 0.01 a$ & $17.95 \pm 1.00 \mathrm{~b}$ & $8.96 \pm 0.03 b$ & $0.92 \pm 0.02 \mathrm{a}$ & $9.70 \pm 0.22 c$ & $148.84 \pm 4.56 a$ & $9.58 \pm 0.09 b$ \\
\hline
\end{tabular}

Abbreviations: $\mathrm{AK}$, available potassium; $\mathrm{AP}$, available phosphorus; $\mathrm{CL}$, cultivated land; $\mathrm{C} / \mathrm{N}$, carbon and nitrogen ratio; DNC, disturbed non-cultivated land; EC, soil electrical conductivity; NCND, non-cultivated non-disturbed land; SM, soil moisture; TN, total nitrogen. Data (means $\pm \mathrm{SE}, \mathrm{n}=3)$ and different letters $(\mathrm{a}, \mathrm{b}, \mathrm{c})$ in the same column indicate significant differences between contrasting land use types at $P<0.05$.

\subsection{Determination of AM Colonization}

Fresh roots, after being fixed with FAA ( $5 \mathrm{~mL}$ formaldehyde, $5 \mathrm{~mL}$ acetic acid, and $90 \mathrm{~mL} 50 \%$ ethanol) for $\geq 48 \mathrm{~h}$, were rinsed with tap water and then cut into $1 \mathrm{~cm}$ segments. The roots were firstly cleared with $10 \%(w / v) \mathrm{KOH}$ for $1 \mathrm{~h}$ at $90{ }^{\circ} \mathrm{C}$, bleached with $\mathrm{H}_{2} \mathrm{O}_{2}$ for 30 min., acidified in $5 \% \mathrm{HCl}$ for $8 \mathrm{~min}$., and finally stained with $5 \%$ Hero blue dark ink (in white vinegar, the ink was commercially from the Hero Ink Factory, Shanghai, China) for $3 \mathrm{~min}$. at $20^{\circ} \mathrm{C}$ [33]. After being rinsed with tap water, the roots were preserved in lactoglycerol at $20^{\circ} \mathrm{C}$. Root $\mathrm{AM}$ fungal colonization was examined under a compound-light microscope (Zeiss Axio Lab A1, Oberkochen, Germany) and determined by the magnified intersections method [34].

\subsection{Extraction of Soil and Root DNA and Amplicon Generation}

Plant DNA was extracted from $0.5 \mathrm{~g}$ roots while using a Plant DNA extraction kit (Tiangen Biotech, Beijing, China), while soil DNA was extracted with $0.5 \mathrm{~g}$ soil using a Fast DNA spin kit for soil (Tiangen Biotech, Beijing, China), according to the manufacturer's protocols. Root and soil DNA extracts were both used for PCR after a 1:10 dilution with distilled water. The ITS2 fragment of 290-328 base pair (bp) was firstly amplified with the AMF-specific primer mixtures of SSUmAf (mixture of SSUmAf1 and SSUmAf2, Table S7) and LSUmAr (mixture of LSUmAr1, LSUmAr2, LSUmAr3, and LSUmAr4, Table S7) [35], and then performed a nested PCR with the general eukaryote primer ITS4 [36] and a newly designed forward fungal specific primer ITS70 [37,38] (Table S7). All of the PCR reactions were carried out in $30 \mu \mathrm{L}$ reactions with $15 \mu \mathrm{L}$ of Phusion ${ }^{\circledR}$ High-Fidelity PCR Master Mix (New England Biolabs, Massachusetts, USA); $0.2 \mu \mathrm{M}$ of forward and reverse primers (SSUmAf and LSUmAr, ITS70, and ITS4, respectively), and about 10 ng template DNA. The first round thermal cycling consisted of initial denaturation at $95{ }^{\circ} \mathrm{C}$ for $1 \mathrm{~min}$., followed by 38 cycles of denaturation at $95{ }^{\circ} \mathrm{C}$ for $30 \mathrm{~s}$, annealing at $60^{\circ} \mathrm{C}$ for $90 \mathrm{~s}$, and elongation at $72{ }^{\circ} \mathrm{C}$ for $2 \mathrm{~min}$., finally $72{ }^{\circ} \mathrm{C}$ for $5 \mathrm{~min}$. The second round thermal cycling consisted of initial denaturation at $94{ }^{\circ} \mathrm{C}$ for 4 min., followed by 35 cycles of denaturation at $94^{\circ} \mathrm{C}$ for $30 \mathrm{~s}$, annealing at $49^{\circ} \mathrm{C}$ for $30 \mathrm{~s}$, and elongation at $72{ }^{\circ} \mathrm{C}$ for $90 \mathrm{~s}$, finally $72{ }^{\circ} \mathrm{C}$ for $10 \mathrm{~min}$. The loading buffer (Takara, Kyoto, Japan) was mixed 
with the same volume of PCR products and the electrophoresis was operated on $2 \%$ agarose gel for estimating the quantity of PCR products. Subsequently, the obtained PCR products were purified with a GeneJET Gel Extraction Kit (Thermo Scientific, Waltham, MA, USA) and the purified amplicons were pooled in equimolar concentrations. The sequencing libraries were generated while using an NEB Next ${ }^{\circledR}$ Ultra $^{\mathrm{TM}}$ DNA Library Prep Kit (New England Biolabs, Massachusetts, USA) for Illumina following the manufacturer's recommendations, and index barcodes were added. The library quality was assessed on the Qubit ${ }^{\circledR}$ 2.0 Fluorometer (Thermo Scientific, Waltham, MA, USA) and Agilent Bioanalyzer 2100 system (Agilent Technologies Co. Ltd., Santa Clar, CA, USA). The library was finally sequenced on an Illumina MiSeq platform (Novogene Bioinformatics Technology Co. Ltd., Beijing, China).

\subsection{Bioinformatics Analysis}

The raw sequence data were filtered while using QIIME v. 1.5.0 (Quantitative Insights into Microbial Ecology, [39]) to remove low-quality reads with an average quality score $<20$, no valid primer sequence or barcode sequence, ambiguous bases $>5$. The ITS2 region of filtered sequences was extracted using the fungal ITSx software package [40], and then potential chimeras were detected using the chimera.uchime command in Mothur 1.31.2 [41] by comparison with entries in the unified system for the DNA-based fungal taxa linked to the classification (UNITE) database [42]. The non-chimeric ITS2 sequences were clustered into operational taxonomic units (OTUs) at a $97 \%$ sequence similarity via the UPARSE pipeline [43] after the de-replication and discard of all singletons. A representative sequence of each OTU was selected and aligned against the NCBI, UNITE, and international nucleotide sequence databases collaboration while using the basic local alignment search tool $[44,45]$. A neighbor joining tree of the representative OTU sequences obtained in this study and reference sequences from GenBank were constructed using the $p$-distance model with 1000 replicates to produce bootstrap values to identify the obtained AMF OTUs. Fungal OTUs were identified as AMF if they matched well with the known AMF taxa and lineages according to the nomenclature of Glomeromycota (http: //www.amf-phylogeny.com and [46]). The numbers of reads per sample were rarefied to the smallest sample size via the sub.sample command in mothur 1.31.2 to remove the effects of uneven sequence depths among samples on the AMF community analysis [41].

\subsection{Data and Statistical Analyses}

The permutation multivariate analysis of variance (PERMANOVA) approach, followed by a Monte Carlo permutational test $(n=999)$, was carried out to compare the differences in the abundance of each OTU among the NCND, DNC, and CL lands. The permutation analysis for the multivariate homogeneity of dispersions (PERMDISP; [47]) with the "adonis" and "betadisper" functions of the vegan package of $R$ version 3.4.3, respectively [48]. The $\beta$-diversity values that were used in the PERMANOVA and PERMDISP analyses were calculated with the "Bray-Curtis" metric based on the OTU-level matrices (Table S5). Soil properties, AMF colonization values, and diversity index among these three lands were also tested by one-way ANOVA.

AMF communities in C. dactylon roots and rhizosphere soil were ordinated (two-dimensional solution) based on OTU matrices while using nonmetric multidimensional scaling (NMDS) to elucidate the influence of land-use type and soil properties on the AMF community. To explore the correlations between each community and the corresponding environmental factors, soil variables and land-use type were fitted as vectors onto the NMDS plots using the function 'envfit' from the 'vegan' library of the $R$ package [49]. The PERMANOVA was carried out with the vegan package in the $R$ version 3.4.3 to establish whether significant differences in AMF community composition existed between land-use types (R Development Core Team, 2013) [48]. 


\subsection{Accession Number}

All Illumina MiSeq Platform sequencing data were deposited in the sequence read archive of public NCBI database under the accession number SAMN05773093- SAMN05773102, SAMN05773138 - SAMN05773145, SRP156764, and SRP156765.

\section{Results}

\subsection{Differences in Soil Properties between Three Contrasting Land-Use Types}

Soil electrical conductivity (EC) was higher at both NCND and DNC than at CL (Table 1). The soils were alkaline ( $\mathrm{pH} 8.18-8.28)$ with a lower $\mathrm{pH}$ value at the non-cultivated non-disturbed land (NCND) than at both the cultivated land (CL) and disturbed non-cultivated land (DNC). Soil available phosphorus (AP), organic carbon (SOC), and moisture (SM) were significantly higher at NCND, followed by at CL and DNC. Soil available potassium (AK) and total nitrogen (TN) ranked as CL $>$ NCND $>$ DNC.

\subsection{Differences between Soil and Root DNA Sequences}

A total of 226,845 and 229,302 ITS2 sequencing reads were respectively obtained from rhizosphere soils and the roots of $C$. dactylon, respectively. Among the Miseq sequencing tags from the soil, the total number of Glomeromycota were 148,615 (65.51\% of all reads from the rhizosphere soil, Table S6), according to the QIIME blast results from the UNITE and INSD database. These sequences from the soil were assigned to 518 OTUs at a $97 \%$ similarity level (belonging to nine genus and 35 taxa, see Table S2). The neighbor-joining phylogenetic tree showed the relationships of the representative sequences of OTUs and referenced sequences from the NCBI and UNITE database (Figure S1 and Table S8). As for the roots, a total of 229,302 Glomeromycota sequences (70.23\% of all tags from the root, Table S6) were assigned to 295 OTUs at a $97 \%$ similarity level (belonging to eight genus and 26 taxa, see Table S3). A total of 37 AMF taxa were observed from the rhizosphere soil (35 taxa) and root (26 taxa).

\subsection{AMF Community Structure in Rhizosphere Soils under Three Contrasting Land-Use Types}

The AMF communities in the rhizosphere soils were determined based on the relative abundance of AMF sequence tags. The most abundant genera in the rhizosphere soils of $C$. dactylon were Glomus and Rhizophagus in all of these three lands (NCND, CL, and DNC), followed by Paraglomus, Claroideoglomus, Septoglomus, Diversispora, Funneliformis, Dominikia, and Archaeospora (Figure 2). A total of 35 AMF taxa were detected from all these lands (Figure $2 \mathrm{~d}$ and Table S2). A greater relative abundance of an AMF genus in rhizosphere soils at NCND was ranked as Rhizophagus $>$ Paraglomus $>$ Glomus, while Glomus > Rhizophagus > Septoglomus at DNC and Glomus > Claroideoglomus > Dominikia at CL (Figure 2). At the taxa level, the most frequent taxa were Rhizophagus intraradices $(12.90 \%)$, followed by Glomeraceae sp. (10.19\%) at NCND. By contrast, the abundant AMF taxa were Glomeraceae sp. $(15.61 \%)$ and Glomus sp. $(11.90 \%)$ at CL. At DNC, the most frequent taxa were Glomeraceae sp. $(24.17 \%)$ and Glomerales sp. (16.38\%). In addition, the Par2 Paraglomus sp., Archaeosporales sp., and Diversispora eburnea were found in the rhizosphere soil at NCND only; Archaeospora sp., Glomus sp. 8 SUN_2011, Glomus microcarpum, and Glomus cubense were in the rhizosphere soil at CL only; whereas the Archaeosporaceae sp. was in the rhizosphere soil at DNC only (Figure 2 and Table S2). 

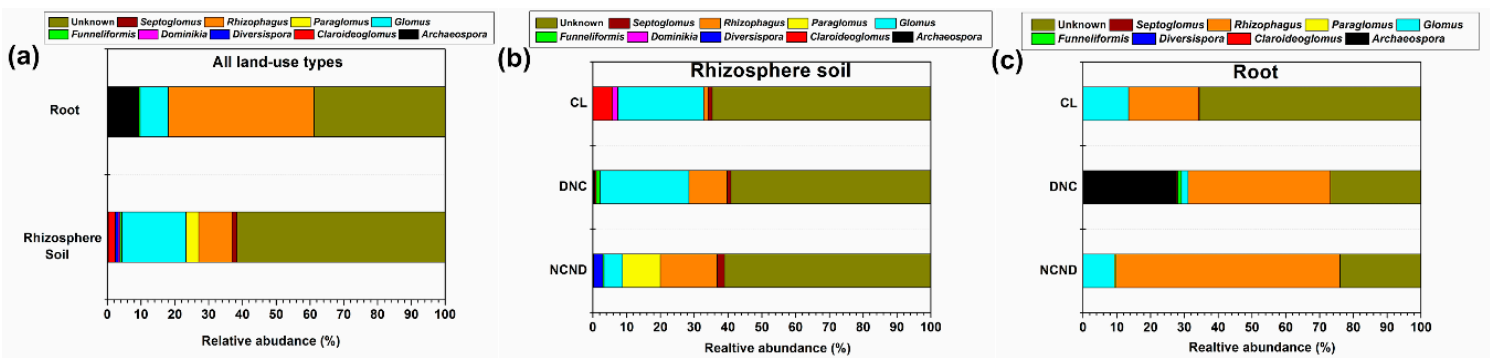

(d)
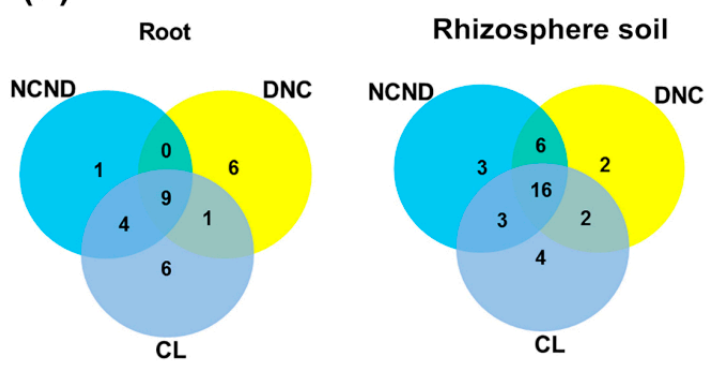

(e)

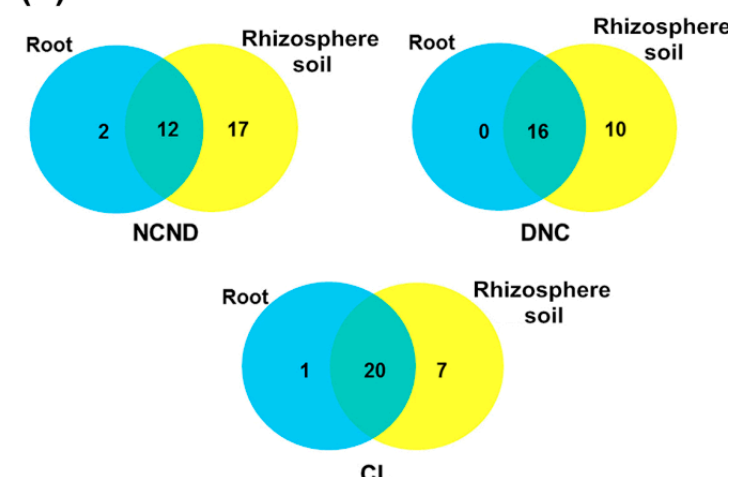

Figure 2. Variations of relative abundances of arbuscular mycorrhizal fungal (AMF) taxa in the roots or rhizosphere soils of $C$. dactylon in all of the three land-use types (a), in the rhizosphere soils (b), roots (c), the Venn diagram of AMF taxa among three contrasting land-use types (d) and between soils and roots under each land-use type (e) along the drawdown zone of Three Gorges Reservoir. NCND (non-cultivated non-disturbed land), DNC (disturbed non-cultivated land), and CL (cultivated land).

\subsection{AMF Community Structure in Roots under Three Contrasting Land-Use Types}

Rhizophagus was the most frequent genus in the roots of $C$. dactylon from all three land types (Figure 2), followed by Archaeospora, Glomus, Funneliformis, Septoglomus, Claroideoglomus, and Diversispora. A total of 26 AMF taxa were observed in roots of $C$. dactylon from the lands (Figure 2d). A greater relative abundance of an AMF genus in rhizosphere soils at NCND ranked as Rhizophagus > Glomus > Paraglomus, while Rhizophagus > Archaeospora > Glomus at DNC and Rhizophagus $>$ Glomus $>$ Septoglomus at CL (Figure 2). At the taxa level, the most dominant genera in roots were Rhizophagus intraradices (39.38\%) and Rhizophagus irregularis, (19.33\%) at NCND, Glomeraceae sp. (15.07\%) and Rhizophagus intraradices (13.54\%) at CL, while Rhizophagus sp. (21.87\%), Archaeosporaceae sp. $(27.57 \%)$ and Rhizophagus irregularis (9.26\%) at DNC (Table S3). Additionally, the exclusive AMF taxa in roots were Claroideoglomus walker, Claroideoglomeraceae sp., Diversispora sp., Diversisporaceae sp., Glomus versiforme, and Rhizophagus custos at DNC and Glomus sp. 0502 at NCND; while, Glomus aggregatum, Glomus cubense, Glomus indicum, Glomus sp., Glomus microcarpum, and Rhizophagus fasciculatus at CL (Table S3).

\subsection{Defferences of AMF Community Structure between Rhizosphere Soils and Roots under Three Contrasting Land-Use Types}

Interestingly, under all the three contrasting land-use types, the abundance of AMF in the rhizosphere soil differed from that in roots at the AMF genus level. For example, the genus Glomus had more taxa in the rhizosphere soils at CL and DNC than that in the corresponding roots (Figure 2). Expectedly, the genus Rhizophagus was more abundant in the roots due to its behavior (life cycle) than that in the corresponding rhizosphere soils at CL, DNC, and NCND (Figure 2). We also found that the abundance of the same AMF taxa in the rhizosphere soil was not in parallel with those in the roots under three land-use types. As shown in Table S2 and S3, Rhizophagus irregularis and Rhizophagus sp. 
were more abundant in the roots of $C$. dactylon than in its corresponding rhizosphere soils at NCND or DNC (Figure 3 or Tables S2 and S3). In contrast, Glomerales sp. was abundant in the rhizosphere soils under C. dactylon, while it was less in C. dactylon roots at DNC (Tables S2 and S3). Meanwhile, AMF community in roots differed from those in the rhizosphere soil. For instance, Glo11 (Glomus sp. 0502) was exclusively observed in the roots; while, several taxa (i.e., Archaeosporales sp., Archaeospora sp., Claroideoglomus luteum) were exclusively in the rhizosphere soil (Tables S2 and S3).

(a)

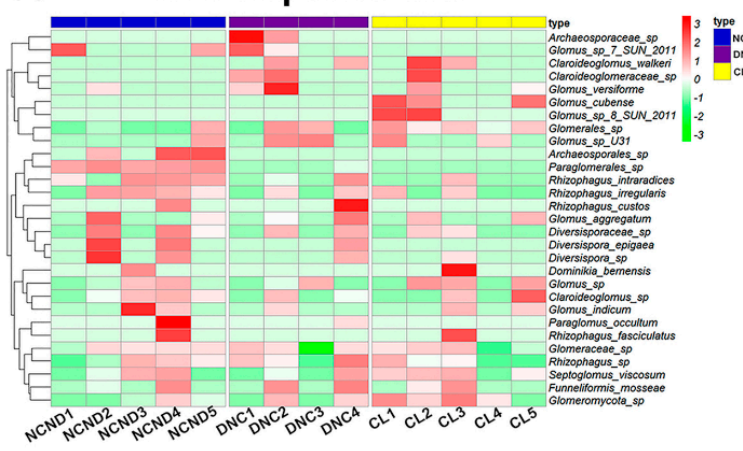

(b)

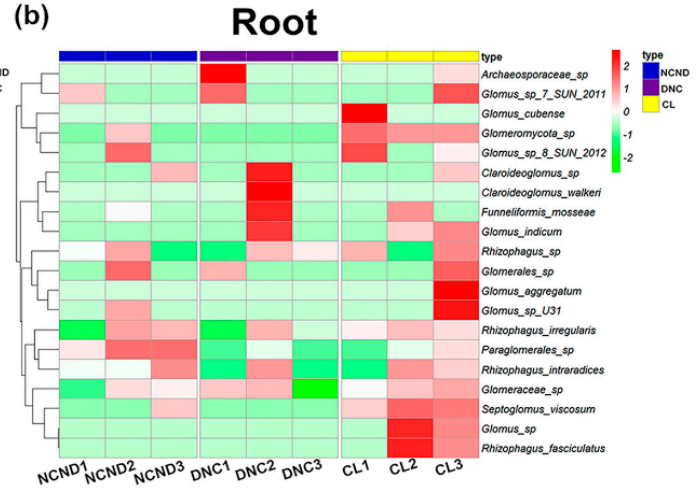

Figure 3. Heatmaps of top thirty relative abundances of arbuscular mycorrhizal fungus (AMF) indicating taxa were significantly differed in rhizosphere soils (a) and roots (b) of $C$. dactylon along the drawdown zone of the Three Gorges Reservoir. The 14 columns represent the individual sampling blocks in the NCND (non-cultivated non-disturbed land), DNC (disturbed non-cultivated land) and CL (cultivated land). The scale bar indicates the abundance of AMF taxa (-3/-2 represents minimum, 3/2 represent maximum). Abbreviations: CL1: C. dactylon from CL; CL2: C. dactylon from CL; CL3: C. dactylon from CL; CL4: C. dactylon from CL; CL5: C. dactylon from CL; DNC1: C. dactylon from DNC; DNC2: C. dactylon from DNC; DNC3: C. dactylon from DNC; DNC4: C. dactylon from DNC; DNC5: no hint obtained after the NGS sequencing; NCND1: C. dactylon from NCND; NCND2: C. dactylon from NCND; NCND3: C. dactylon from NCND; NCND4: C. dactylon from NCND; NCND5: C. dactylon from NCND.

\subsection{AMF $\alpha$-Diversity, Colonization and Community under Three Contrasting Land-Use Types Lands}

The values of AMF OTUs and asymptotic AMF taxon richness (Chao1) were significantly $(P<0.05)$ higher in the roots at $C L$ than at NCND, and the values of $\alpha$-diversity were lowest at DNC in rhizosphere soils or roots (Table 2). CL had the highest Shannon-Wiener index in rhizosphere soil and roots, followed by NCND and DNC. In contrast, a significantly higher root AMF colonization ranked as it was followed by $\mathrm{DNC} \approx \mathrm{CL}>\mathrm{NCND}$. Meanwhile, root AMF colonization significantly positively related to soil $\mathrm{pH}(r=0.71, P<0.001)$ or moisture $(r=0.45, P<0.05)$, but negatively to soil available phosphorus $(r=-0.37, P<0.05)$. 
Table 2. Mycorrhizal colonization and diversity of arbuscular mycorrhizal fungi (AMF) taxa in the rhizosphere soil and root of $C$. dactylon grown in three contrasting land types along the drawdown zone of Three Gorges Reservoir.

\begin{tabular}{ccccc}
\hline & MC (\%) & OTUs & Chao 1 & Shannon-Wiener \\
\hline Rhizosphere soil & & & & \\
NCND & - & $71 \pm 21.40(\mathrm{a}, \mathrm{x})$ & $80.19 \pm 21.64(\mathrm{a}, \mathrm{x})$ & $4.05 \pm 0.47(\mathrm{a}, \mathrm{x})$ \\
DNC & - & $40 \pm 20.66(\mathrm{a}, \mathrm{x})$ & $42.38 \pm 20.93(\mathrm{a}, \mathrm{x})$ & $2.99 \pm 0.72(\mathrm{a}, \mathrm{x})$ \\
CL & - & $63 \pm 12.99(\mathrm{a}, \mathrm{x})$ & $64.40 \pm 13.68(\mathrm{a}, \mathrm{x})$ & $4.16 \pm 0.45(\mathrm{a}, \mathrm{x})$ \\
\hline Root & & & & \\
NCND & $20.15 \pm 2.45(\mathrm{c}, \mathrm{x})$ & $47 \pm 24.00(\mathrm{ab}, \mathrm{x})$ & $49.33 \pm 27.00(\mathrm{ab}, \mathrm{x})$ & $3.32 \pm 0.20(\mathrm{ab}, \mathrm{x})$ \\
DNC & $31.85 \pm 4.76(\mathrm{~b}, \mathrm{x})$ & $23 \pm 1.86(\mathrm{~b}, \mathrm{x})$ & $24.00 \pm 1.86(\mathrm{~b}, \mathrm{x})$ & $2.42 \pm 0.12(\mathrm{~b}, \mathrm{x})$ \\
CL & $29.00 \pm 2.17(\mathrm{a}, \mathrm{x})$ & $76 \pm 20.90(\mathrm{a}, \mathrm{x})$ & $82.50 \pm 22.18(\mathrm{a}, \mathrm{x})$ & $3.92 \pm 0.59(\mathrm{a}, \mathrm{x})$ \\
\hline
\end{tabular}

The $\alpha$-diversity index is presented as the number of detected operational taxonomic units (OTUs); the number of estimated asymptotic AM fungal taxon richness (Chao 1) and the Shannon-Wiener index. CL, cultivated land; DNC, disturbed non-cultivated land; MC: mycorrhizal colonization; NCND, non-cultivated non-disturbed land. Data (means $\pm \mathrm{SE}, n=5$ for soil, $n=3$ for root) and different letters indicate significant differences between land use types in the same Soil or Root category $(\mathrm{a}, \mathrm{b}, \mathrm{c})$ or between Soil and Root for the same land use type $(\mathrm{x}, \mathrm{y})$ at $P<0.05$.

The NMDS analysis showed significant differences in AMF community composition in rhizosphere soils or roots between three contrasting land-use types (Figure 4). The distance was calculated with the "Bray-Curtis" metric. The stress was 0.131 for rhizosphere soil and 0.070 for root. Such differences were confirmed by the PERMANOVA in the rhizosphere soil and/or root for the three land use types $(\mathrm{F}=1.32, P=0.023 ; \mathrm{F}=2.01, P=0.001$ and $\mathrm{F}=1.14, P=0.168$, respectively, Table S5). Moreover, the PERMDISP analyses also showed that beta diversity differences in the rhizosphere soils and/or roots were not significant under the three contrasting land-use types $(P>0.05$, Table S5).

(a)

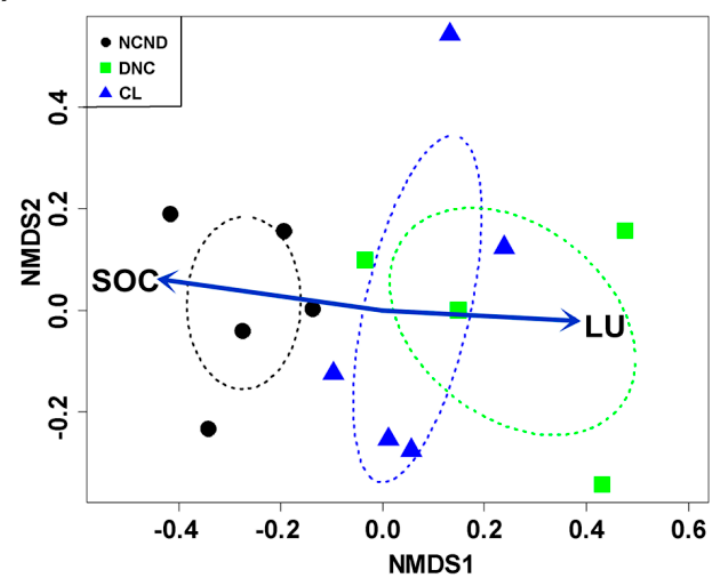

(b) Root

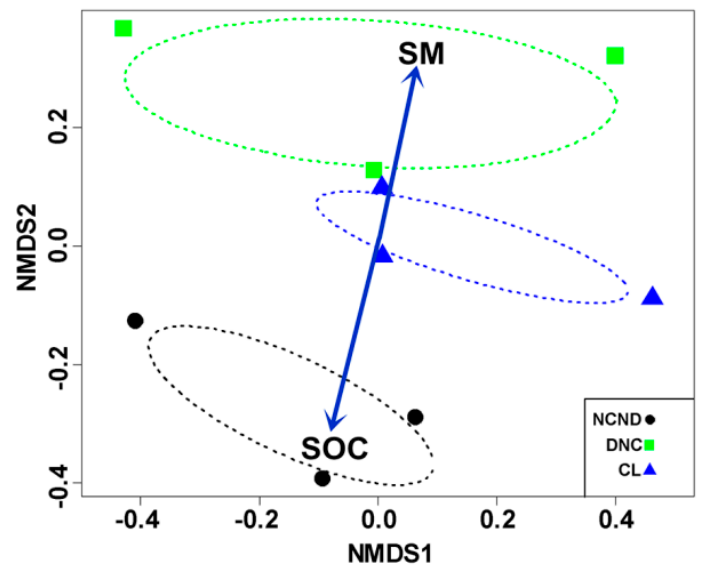

Figure 4. Nonmetric multidimensional scaling (NMDS) ordinations of arbuscular mycorrhizal fungus (AMF) community composition based on the Bray-Curtis dissimilarity in both the rhizosphere soils (a) and roots (b) of C. dactylon along the drawdown zone of Three Gorges Reservoir. The three contrasting land-use types were fitted as centroids onto the NMDS graph (stress $(\mathbf{a})=0.131$; stress $(\mathbf{b})=0.070$ ) LU, land-use type; SOC, soil organic carbon; SM, soil moisture.

\subsection{Effects of Abiotic Factors on the AMF Community between Rhizosphere Soils and Roots}

The relationships between AMF (in the rhizosphere soil and root) community composition and land-use type or basic soil properties were determined by the NMDS analysis tht was based on their OTU matrix (Figure 4 and Table S4). Soil organic carbon was significantly positively related to AMF community in the rhizosphere soils and/or roots. In addition, land-use type was significantly correlated to AMF community in the rhizosphere soils of $C$. dactylon only, while to soil moisture in the roots that are associated with $C$. dactylon only (Figure 4 and Table S4). 


\section{Discussions}

\subsection{Differences in AMF Communities in Rhizosphere Soils and Roots}

Based on the obtained amplicon sequences through the high-throughput analyses, our study compared the AMF community assemblages in C. dactylon roots and rhizosphere soils among three contrasting land-use types in the Three Gorges Reservoir (TGR) area. The proportions of the same AMF genus in the rhizosphere soils did not parallel with those in the roots. The AMF genus proportions of roots/rhizosphere soils ranged from $8.2 \%$ to $18.5 \%, 43.0 \%$ to $9.7 \%$ and $9.2 \%$ to $0.3 \%$ for Glomus, Rhizophagus, and Archaeospora, respectively, when differentiating the distinct AMF genera under these three contrasting land-use types (Figure 2a). This is in accordance with results from studies in AMF community between roots (natural shrubs or herbaceous species) and soils (silt-loamy or flat Haplic Cambisols texture) from non-submerged terrestrial ecosystems [50,51]. The differences of AMF communities between soils and roots could be due to a more heterogeneous rhizosphere soil and the seasonal nature of AMF communities [52]. For example, the formerly active AMF propagules (e.g., arbuscules, spores, and extra-radical mycelia) still presented in the rhizosphere soils, in addition to propagules of current symbionts [48]. On the other hand, the preference of AMF for the plant root was also observed in several studies [52,53]. For instance, Rhizophagus was more abundant in roots than in soil, due to its behavior (life cycle) and characteristics [12]. It has been demonstrated that the Rhizophagus irregularis/intraradices group possesses numerous genes that encode transporters and played vital roles in nutrient uptake between AMF and host plant [54,55].

Additionally, the AMF taxa had strong overlap between the rhizosphere soils and roots in our study, especially at the cultivated land (CL) (Figure 2e). Similar results were found by Chen et al. [56], who revealed that the AMF community in the Haplic Calcisol soil was strongly overlapped with that in the roots in a temperate steppe in Inner Mongolia, China. However, the mechanism determining the overlap of AMF community between the soils and mixed roots is largely unknown. An explanation was that the mutualistic characteristics of AMF propagules and the frequent interplay between AMF and host plants, which leads to an overlap of AMF community between the rhizosphere soils and roots [56]. All together, these findings indicated that a moderate disturbance could lead to a positive interaction in AMF community between rhizosphere soils and the host roots (Figure 2).

\subsection{Differences in AMF Colonization, Diversity and Community in the Rhizosphere Soils and Roots under Three Contrasting Land-Use Types}

Intermittent flooding environments in wetland habitats could cause stress on plants that might lead to slow rates of respiration and photosynthesis of plants due to the hampered availability of $\mathrm{O}_{2}, \mathrm{CO}_{2}$, and/or light [57]. In this study, the AMF colonization in the flooding-tolerant host roots of C. dactylon was significantly higher at the disturbed non-cultivated (DNC) land than at the non-cultivated non-disturbed (NCND) and cultivated land (CL) (Table 2). This might be due to a higher soil pH but lower soil moisture, toxic substances, and availability of oxygen, nitrogen, phosphorus, potassium, or other nutrients at DNC or CL than at NCND (Table 1), which could increase the AMF colonized roots [58]. This is inconsistent with a previous report in a wetland habitat, moderate flooding increased the AMF colonization in the roots of an aquatic species (Polygonum hydropiper), and intensive flooding inhibited the AMF colonization in the roots of $P$. hydropiper [29]. An explanation was that the moderate flooding greatly increased the number of adventitious roots and promoted the development of root aerenchyma in P. hydropiper, while promoting the efficiency of root oxygen release and the growth of P. hydropiper [59]. While considering the obligate symbiotic nature of AMF and their requirement for oxygen and nutrients to thrive [12], it is possible that their AM colonization of wetland hosts in TGR, might be enhanced by a moderate disturbance, while being decreased by excessive disturbance. However, the two sets of results might not be comparable since the AMF colonization had been detected under summer flooding in their studies [27,58,59], whereas under winter flooding in the present study, 
in addition to different host plants were examined. Indeed, AMF colonization is affected by the host plant identity [60,61].

Although studies had shown that tillage or land-use changes could display negative or no effects on AMF diversity [62-66], AMF diversity in both the rhizosphere soils and roots associated with C. dactylon in this study was significantly higher at CL than at DNC, and then at NCND (Table 2). Explanations for such different effects could be (1) the host plants that were tested were different, $C$. dactylon in this study was a flooding-tolerant herbaceous plant with adventitious roots and aerenchyma, as AMF diversity was affected by the host plant identity [60,61]; (2) the land-use intensity was different, as the AMF diversity was affected by land-use intensity [67]. Thus, such effects may depend on region-specific factors, including host characteristics, environmental conditions, and land-use intensity $[29,68,69]$. On the one hand, this present study did show a higher AMF richness and diversity in the rhizosphere soils than in roots, which is consistent with findings from Pellegrino et al. [70] and Moora et al. [67]. On the other hand, the aboveground biomass production and composition of the plant species, and the type of disturbance did affect AMF symbionts in the roots greatly [71,72].

Apparently, differences in the distribution of the same AMF genus or taxa existed among these three land-use type lands (Figure 2), and the overlapped taxa were increased with the land-use intensity (Figure 2e). This is consistent with the findings that arable farming and associated tillage generally favored the colonization of AMF within the Glomeraceae family or Glomus genus [73]. Additionally, our study strengthened the fact that land-use intensification greatly altered AMF compositions [67]. Meanwhile, the AMF taxa in compatible with arable soils corresponded well to those found in a number of other studies [50,74,75]. For instance, Funneliformis mosseae and Glomus versiforme had been recognized as common taxa in the clay loams of Denmark [75]. Such results might indicate that these AMF taxa could be globally distributed in a broad range of soil types. In contrast, the distributions of several taxa (e.g., Archaeosporales sp. and Diversispora eburnea) were restricted to the NCND land (Table S2). These taxa dominantly existed in the fine textured soils [76], which suggested that AMF had some degree of either specialization or restriction to land-use types. These findings have indicated that the AMF communities in drying-wetting environments would include some specific AMF taxa in the TGR region and also some common taxa existing in other habitats. Whether the dominant AMF taxa (e.g., Funneliformis mosseae and Glomus versiforme) or specific taxa (e.g., Diversispora eburnea) can be used as biofertilizer in the vegetation restoration remains to be clarified in future studies.

\subsection{Correlations of Differences between AMF Community and Relevant Abiotic Factors}

C. dactylon have well-developed adventitious roots and aerenchyma to adapt to specific wetland habitats [77], which can obtain more carbohydrates and oxygen to support a high diversity of AMF communities in their soils and roots under waterlogged conditions. A range of characteristics, such as soil properties and anthropogenic activities (e.g., tillage, chemical fertilization and land-use types) etc., were different from each other at NCND, DNC, and CL (Table 1). Among them, which factor could contribute most to the differences in AMF community between rhizosphere soils and roots? Interestingly, SOC was one of the primary contributors to affect the AMF community both in the rhizosphere soils and roots of $C$. dactylon (Figure 4, Table S4). Studies have confirmed that the AMF communities in the soils along a large-scale aridity gradient from southeast to northwest of China and tropical savannas soils of Brazil were generally mediated through SOC [78,79]. It was speculated that a higher SOC could satisfy more AMF spores and mycelium germination, which demand for carbohydrates, thus directly affecting the AMF community composition in the rhizosphere soils or roots [78,79]. Nonetheless, it remains unknown as to how SOC directly regulate AMF community, and further work needs to pay more attention to this issue.

Besides, nonmetric multidimensional scaling (NMDS) analyses indicated that land-use type was also a primary contributor to affect AMF community in the rhizosphere soils of $C$. dactylon (Figure 4, Table S4). Previous studies have demonstrated that the AMF communities in the sub-Saharan savannas soils of West Africa and temperate climatic zone soils of Central Europe were generally mediated 
through land-use type or intensity $[66,80]$. An explanation might be that land-use type could alter soil abiotic properties, such as soil available phosphorus and $\mathrm{C} / \mathrm{N}$ ratio, thus influencing the AMF community in the rhizosphere soils. On the other hand, the use of fertilizers and human activities in cultivated or disturbed land has selectively regulated the abundance and composition of AMF taxa that are able to tolerate such disturbances. Similarly, other studies also showed that land-use types (e.g., tillage methods) could influence soil microbial activity and structure by influencing the habitat of soil microbes, such as soil texture and microbial substrates, thus affecting soil nutrients and the AMF community $[81,82]$. In contrast, soil moisture was only significantly correlated with AMF community in the $C$. dactylon root (Figure 4, Table S4). This is consistent with previous studies that soil nutrients (e.g., soil moisture) had different correlations with AMF community in the central Tibet Plateau between rhizosphere soils and roots [83]. Changes in moisture altered $\mathrm{N}$ and $\mathrm{P}$ availability in soil, thereby altering AMF community composition and diversity [84]. Nonetheless, it is difficult to separate the effects of soil property and land-use type on AMF. Thus, further research is needed to uncover how major macronutrients could regulate differences in their AMF community between the rhizosphere soils and roots that are associated with the same or different vegetation.

\subsection{Primer Systems for Evaluating AMF Community}

Different primer systems have been developed to characterize AMF communities [35,37,85,86]. Kohout et al. [38] compared five AMF-specific primer sets for nuclear ribosomal DNA covering (1) the partial large subunit (LSU), (2) the partial small subunit (SSU), (3) the partial small subunit and internal transcribed spacer (ITS), (4) the partial SSU-ITS-partial LSU region (Krüger, [35]), and (5) a new primer set covering the ITS2 region (ITS2). The AMF-specific primer (AML1/AML2) in SSU can also amplify a significant proportion of plant DNA when compared with other primers [63]. Moreover, the SSU primers (NS31/AML2) showed a high extent co-amplifies Asco- and Basidiomycota [38,83]. Congruent with previous reports, a strong bias towards the Glomeraceae in the LSU primers, which discriminate several Glomeromycota lineages, such as the Diversisporaceae [87], Paraglomeraceae, Claroideoglomeraceae, and Archaeosporales, has been found [35]. Similarly, a high extent of non-specific amplification has been found with the "ITS" primers, which yield both non-target AMF and non-AMF sequences that are supported by previous reports [88]. The newly forward primer ITS70 [37] could amplify the ITS2 region in combination with the ITS4 primer, which could detect all of the AMF families that were revealed by the "Krüger" primers [35]. As demonstrated by Stockinger et al. [86], the ITS or ITS2-LSU region has high resolution for the AMF taxa, as a suitable target fragment for their high-throughput sequencing. However, an appropriate forward primer for amplifying this region is not available, as the ITS3 primer largely mismatches with AMF taxa from Ambisporaceae, Rhizophagus, Sclerocystis, and Acaulospora [89]. The ITS70 primer, which overcomes these problems, when combined with the ITS4 as a reverse primer, can be used for the second step of a nested PCR approach, if following the AMF-specific amplification by the "Krüger" primers SSUmAf/LSUmAr in the first step [35]. When considering that the Krüger primers can amplify more than 1485 base pair (bp) DNA fragments, this primer combination might be especially suitable for using the new next generation sequencing (NGS) approach-Illumina — which is cheaper than other NGS methods (SMRT-sequencing), but it offers only shorter fragments with a maximal length of $380 \mathrm{bp}$ [90]. Thus, the new AMF-specific primer ITS70/ITS4 could be considered to be a suitable primer set to evaluating arbuscular mycorrhizal fungal communities, but this combination requires further testing.

\section{Conclusions}

In the drawdown zone of the TGR, higher AMF diversity and distinctive AMF taxa were displayed in rhizosphere soils than in roots of $\mathrm{a}_{4} \mathrm{C}$. dactylon under three contrasting land-use lands. A clear differentiation on AMF community composition was detected in the rhizosphere soils and roots of $C$. dactylon. Soil organic carbon had significant effects on the AMF community in both rhizosphere soils and roots. In addition, AMF communities in rhizosphere soils specifically correlated to land-use 
type, whereas in roots to soil moisture. We concluded that the difference in AMF community between rhizosphere soils and the roots of $C$. dactylon was due to the synergistic effects of land-use type and soil nutrients. As a result, the inoculation of common taxa (e.g., Funneliformis mosseae and Glomus versiforme) can play vital roles in the vegetation restoration, while considering the nutrients exchange between AMF and C. dactylon in the drying-wetting habitat. Hence, this study could provide insights into the impacts of land-use types on AMF communities in altered drying-wetting habitats while preventing soil degradation and maintaining ecosystem biodiversity around the world.

Supplementary Materials: The following are available online at http:/www.mdpi.com/1424-2818/11/10/197/ s1. Figure S1 Neighbor-joining phylogenetic tree (Maximum Likelihood method) showing the relationships of the representative sequences of OTUs and the reference sequences from GenBank and UNITE; Figure S2 The temperature (a) and rainfall (b) of the sampling sites in the Three Gorges Reservoir from Feb (February) to Nov (November) in 2014; Table S1 Specific information on the sampling sites; Table S2 Relative abundance of arbuscular mycorrhizal fungi (AMF) taxa in the rhizosphere soils of Cynodon dactylon in three contrasting land use types along the drawdown zone of the Three Gorges Reservoir; Table S3 Relative abundance (\%) of arbuscular mycorrhizal fungi (AMF) taxa in roots associated with Cynodon dactylon grown in three contrasting land use types along the drawdown zone of the Three Gorges Reservoir; Table S4 Correlation coefficient between arbuscular mycorrhizal fungi (AMF) community composition and environmental variables (soil chemical characteristics and land-use type) from axes 1 and 2 of ordination; Table S5 Permutational multivariate analysis of variance (PERMANOVA) exploring the differences in arbuscular mycorrhizal fungi (AMF) community structure among constrasting land-use types; Table S6 The number of sequencing reads from each fungal phylum detected for all rhizopshre soil or root samples among three contrasting land-use types; Table S7 The PCR primers sequences in this study; Table S8 Molecular identification of arbuscular mycorrhizal (AM) fungi in this study.

Author Contributions: J.D. conceived and designed the experiments; X.L. (Xie Luo), X.L. (Xiumei Luo), Y.L. and J.W. performed the experiments. X.L. (Xie Luo), X.L. (Xiumei Luo), X.H. and J.D. were responsible for the field experiment and provided fund support. X.L. (Xie Luo) analyzed amino acid data with the help of X.L. (Xiumei Luo); X.L. (Xie Luo), X.H. and J.D. wrote the manuscript. All authors approved the final manuscript.

Funding: This research was funded by and Xinhua He, National Key Research and Development Program (2016YFD0200104), Foundation of the Science and Technology Department of Sichuan Province (2018JZ0027), National Science Foundation for Young Scholars (411800096) and a specific grant from Biological Science Research Centre at Southwest University. And Jinyan Dong, Natural Science Foundation of Chongqing (cstc2017jcyjAX0225), also financially supported this study. The APC was funded by the grants of Xinhua He.

Acknowledgments: The authors thank for Qi Jiang from the Southwest University for the help of statistical analyses. We thank two anonymous reviewers for their comments on the manuscript.

Conflicts of Interest: The authors have no conflicts of interest to declare.

\section{References}

1. Wang, Q.; Yuan, X.; Willison, J.H.; Zhang, Y.; Liu, H. Diversity and above-ground biomass patterns of vascular flora induced by flooding in the drawdown area of China's Three Gorges Reservoir. PLoS ONE 2014, 9, e100889. [CrossRef] [PubMed]

2. Yan, T.; Yang, L.; Campbell, C.D. Microbial biomass and metabolic quotient of soils under different land use in the Three Gorges Reservoir area. Geoderma 2003, 115, 129-138. [CrossRef]

3. Osborne, L.L.; Kovacic, D.A. Riparian vegetated buffer strips in water-quality restoration and stream management. Freshw. Biol. 1993, 29, 243-258. [CrossRef]

4. Richardson, D.; Holmes, P.; Esler, K.; Galatowitsch, S.; Stromberg, J.; Kirkman, S.; Pyšek, P.; Hobbs, R. Riparian vegetation: Degradation, alien plant invasions, and restoration prospects. Divers. Distrib. 2007, 13, 126-139. [CrossRef]

5. Yang, Y.; Li, C. Photosynthesis and growth adaptation of Pterocarya stenoptera and Pinus elliottii seedlings to submergence and drought. Photosynthetica 2016, 54, 120-129. [CrossRef]

6. Zhang, Q.; Lou, Z. The environmental changes and mitigation actions in the Three Gorges Reservoir region, China. Environ. Sci. Policy 2011, 14, 1132-1138. [CrossRef]

7. Veach, A.M.; Dodds, W.K.; Jumpponen, A. Woody plant encroachment, and its removal, impact bacterial and fungal communities across stream and terrestrial habitats in a tallgrass prairie ecosystem. FEMS Microbiol. Ecol. 2015, 91, 1-11. [CrossRef]

8. Tenten, N.; Zeng, B.; Kazda, M. Soil stabilizing capability of three plant species growing on the Three Gorges Reservoir riverside. J. Earth. Sci. 2010, 21, 888-896. [CrossRef] 
9. Willison, J.H.; Li, R.; Yuan, X. Conservation and ecofriendly utilization of wetlands associated with the Three Gorges Reservoir. Environ. Sci. Pollut. Res. 2013, 20, 6907-6916. [CrossRef]

10. Wardle, D.A.; Bardgett, R.D.; Klironomos, J.N.; Setälä, H.; van der Putten, W.H.; Wall, D.H. Ecological linkages between aboveground and belowground biota. Science 2004, 304, 1629-1633. [CrossRef]

11. Dam, N.M.V.; Heil, M. Multitrophic interactions below and above ground: En route to the next level. J. Ecol. 2011, 99, 77-88.

12. Smith, S.E.; Read, D.J. Mycorrhizal Symbiosis; Academic Press: Cambridge, UK, 2008; pp. 1-187.

13. Bainard, L.D.; Bainard, J.D.; Hamel, C.; Gan, Y. Spatial and temporal structuring of arbuscular mycorrhizal communities is differentially influenced by abiotic factors and host crop in a semi-arid prairie agroecosystem. FEMS Microbiol. Ecol. 2014, 88, 333-344. [CrossRef] [PubMed]

14. Rillig, M.C.; Mummey, D.L. Mycorrhizas and soil structure. New Phytol. 2006, 171, 41-53. [CrossRef] [PubMed]

15. Wilson, G.W.; Rice, C.W.; Rillig, M.C.; Springer, A.; Hartnett, D.C. Soil aggregation and carbon sequestration are tightly correlated with the abundance of arbuscular mycorrhizal fungi: Results from long-term field experiments. Ecol. Lett. 2009, 12, 452-461. [CrossRef] [PubMed]

16. van der Heijden, M.G.A.; Horton, T.R. Socialism in soil? The importance of mycorrhizal fungal networks for facilitation in natural ecosystems. J. Ecol. 2009, 97, 1139-1150. [CrossRef]

17. Li, L.F.; Li, T.; Zhao, Z.W. Differences of arbuscular mycorrhizal fungal diversity and community between a cultivated land, an old field, and a never-cultivated field in a hot and arid ecosystem of southwest China. Mycorrhiza 2007, 17, 655-665. [CrossRef] [PubMed]

18. Boddington, C.L.; Dodd, J.C. The effect of agricultural practices on the development of indigenous arbuscular mycorrhizal fungi. I. Field studies in an Indonesian ultisol. Plant. Soil 2000, 218, 137-144. [CrossRef]

19. Islam, K.R.; Weil, R.R. Soil quality indicator properties in mid-Atlantic soils as influenced by conservation management. J. Soil Water Conserv. 2000, 55, 69-78.

20. Li, B.; Xiao, H.Y.; Yuan, X.Z.; Willison, J.H.M.; Liu, H.; Chen, Z.L.; Zhang, Y.W.; Deng, W.; Yue, J.S. Analysis of ecological and commercial benefits of a dike-pond project in the drawdown zone of the Three Gorges Reservoir. Ecol. Eng. 2013, 61,1-11. [CrossRef]

21. Helgason, T.; Daniell, T.J.; Husband, R.; Fitter, A.H.; Young, J.P.W. Ploughing up the wood-wide web? Nature 1998, 394, 431. [CrossRef]

22. Muthukumar, T.; Udaiyan, K. Arbuscular mycorrhizas of plants growing in the Western Ghats region, Southern India. Mycorrhiza 2000, 9, 297-313. [CrossRef]

23. Zhao, X.; Yuan, S.; Song, H.; Su, X.; Mao, H.; Shen, W.; Qu, X.L.; Dong, J.Y. Arbuscular mycorrhizal and dark septate fungal associations in riparian plants of the Three Gorges Reservoir Region, Southwest China. Aquat. Bot. 2016, 133, 28-37. [CrossRef]

24. Luo, X.; Su, X.; Cui, J.; Lou, Y.; Li, R.; Luo, X.M.; Zeng, Y.Q.; Xu, Y.B.; Dong, J.Y. Biodiversity of arbuscular mycorrhizal fungi in the drawdown zone of the Three Gorges Reservoir under different fertilization histories. Ecol. Res. 2016, 31, 407-416. [CrossRef]

25. Nielsen, K.B.; Kjøller, R.; Olsson, P.A.; Schweiger, P.F.; Andersen, F.Ø.; Rosendahl, S. Colonisation and molecular diversity of arbuscular mycorrhizal fungi in the aquatic plants Littorella uniflora and Lobelia dortmanna in southern Sweden. Mycol. Res. 2004, 108, 616-625. [CrossRef] [PubMed]

26. Wilde, P.; Manal, A.; Stodden, M.; Sieverding, E.; Hildebrandt, U. Biodiversity of arbuscular mycorrhizal fungi in roots and soils of two salt marshes. Environ. Microbiol. 2009, 11, 1548-1561. [CrossRef] [PubMed]

27. Wang, Y.T.; Huang, Y.L.; Qiu, Q.; Xin, G.R.; Yang, Z.Y.; Shi, S.H. Flooding greatly affects the diversity of arbuscular mycorrhizal fungi (AMF) communities in the roots of wetland plants. PLoS ONE 2011, 6, e24512.

28. Twanabasu, B.R.; Smith, C.M.; Stevens, K.J.; Venables, B.J.; Sears, W.C. Triclosan inhibits arbuscular mycorrhizal colonization in three wetland plants. Sci. Total Environ. 2013, 447, 450-457. [CrossRef]

29. Wang, Y.; Li, Y.; Bao, X.; Björn, L.O.; Li, S.; Olsson, P.A. Response differences of arbuscular mycorrhizal fungi communities in the roots of an aquatic and a semiaquatic species to various flooding regimes. Plant Soil 2016, 403, 361-373. [CrossRef]

30. Ye, C.; Zhang, K.; Deng, Q.; Zhang, Q. Plant communities in relation to flooding and soil characteristics in the water level fluctuation zone of the Three Gorges Reservoir, China. Environ. Sci. Pollut. Res. 2013, 20, 1794-1802. [CrossRef] 
31. Bao, S.D. Soil Agro-Chemistry Analyses; Chinese Agriculture Press: Beijing, China, 2008; pp. 1-100. (In Chinese)

32. Rhoades, J.D. Salinity: Electrical conductivity and total dissolved solids. In Methods of Soil Analysis, Part 3-Chemical Methods; Sparks, D.L., Ed.; American Society of Agronomy: Madison, WI, USA, 1996; pp. 417-436.

33. de Souza, F.A.; Dalpé, Y.; Declerck, S.; de la Providencia, I.E.; Séjalon-Delmas, N. Life history strategies in Gigasporaceae: Insight from monoxenic culture. In In Vitro Culture of Mycorrhizas; Declerck, S., Strullu, D.G., Fortin, J.A., Eds.; Springer: Heidelberg, Germany, 2005; pp. 73-91.

34. Mcgonigle, T.P.; Miller, M.H.; Evans, D.G.; Fairchild, G.L.; Swan, J.A. A new method which gives an objective measure of colonization of roots by vesicular-arbuscular mycorrhizal fungi. New Phytol. 1990, 115, 495-501. [CrossRef]

35. Krüger, M.; Stockinger, H.; Krüger, C.; Schüssler, A. DNA-based species level detection of Glomeromycota: One PCR primer set for all arbuscular mycorrhizal fungi. New Phytol. 2009, 183, 212-223. [CrossRef] [PubMed]

36. White, T.J.; Bruns, T.; Lee, S.; Taylor, J. Amplification and direct sequencing of fungal ribosomal RNA genes for phylogenetics. In PCR Protocols, a Guide to Methods and Applications; Innis, M.A., Gelfand, D.H., Sninsky, J.J., White, T.J., Eds.; Academic Press: San Diego, CA, USA, 1990; pp. 315-322.

37. Ihrmark, K.; Bödeker, I.T.; Cruz-Martinez, K.; Friberg, H.; Kubartova, A.; Schenck, J.; Strid, Y.; Stenlid, J.; Brandström-Durling, M.; Clemmensen, K.E.; et al. New primers to amplify the fungal ITS2 region-evaluation by 454-sequencing of artificial and natural communities. FEMS Microbiol. Ecol. 2012, 82, 666-677. [CrossRef] [PubMed]

38. Kohout, P.; Sudová, R.; Janoušková, M.; Čtvrtlíková, M.; Hejda, M.; Pánková, H.; Slavíková, R.; Stajerová, K.; Vosátka, M.; Sýkorová, Z. Comparison of commonly used primer sets for evaluating arbuscular mycorrhizal fungal communities: Is there a universal solution? Soil Biol. Biochem. 2014, 68, 482-493. [CrossRef]

39. Caporaso, J.G.; Kuczynski, J.; Stombaugh, J.; Bittinger, K.; Bushman, F.D.; Costello, E.K.; Fierer, N.; Peña, A.G.; Goodrich, J.K.; Gordon, J.F.; et al. QIIME allows analysis of high-throughput community sequencing data. Nat. Methods 2010, 7, 335-336. [CrossRef]

40. Bengtsson-Palme, J.; Ryberg, M.; Hartmann, M.; Branco, S.; Wang, Z.; Godhe, A.; Wit, P.D.; Sánchez-García, M.; Ebersberger, I.; de Sousa, F.; et al. Improved software detection and extraction of ITS1 and ITS2 from ribosomal ITS sequences of fungi and other eukaryotes for analysis of environmental sequencing data. Methods Ecol. Evol. 2013, 4, 914-919. [CrossRef]

41. Schloss, P.D.; Westcott, S.L.; Ryabin, T.; Hall, J.R.; Hartmann, M.; Hollister, E.B.; Lesniewski, R.A.; Oakley, B.B.; Parks, D.H.; Robinson, C.J.; et al. Introducing mothur: Open-source, platform-independent, community-supported software for describing and comparing microbial communities. Appl. Environ. Microb. 2009, 75, 7537-7541. [CrossRef]

42. Kõljalg, U.; Nilsson, R.H.; Abarenkov, K.; Tedersoo, L.; Taylor, A.F.; Bahram, M.; Bates, S.T.; Bruns, T.D.; Bengtsson-Palme, J.; Callaghan, T.M.; et al. Towards a unified paradigm for sequence-based identification of fungi. Mol. Ecol. 2013, 22, 5271-5277.

43. Edgar, R.C. UPARSE: Highly accurate OTU sequences from microbial amplicon reads. Nat. Methods 2013, 10, 996-998. [CrossRef]

44. Altschul, S.F.; Gish, W.; Miller, W.; Myers, E.W.; Lipman, D.J. Basic local alignment search tool. J. Mol. Biol. 1990, 215, 403-410. [CrossRef]

45. Abarenkov, K.; Nilsson, R.H.; Larsson, K.H.; Alexander, I.J.; Eberhardt, U.; Erland, S.; Høiland, K.; Kjøller, R.; Larsson, E.; Pennanen, T.; et al. The UNITE database for molecular identification of fungi-recent updates and future perspectives. New Phytol. 2010, 186, 281-285. [CrossRef]

46. Redecker, D.; Schüssler, A.; Stockinger, H.; Stürmer, S.L.; Morton, J.B.; Walker, C. An evidence-based consensus for the classification of arbuscular mycorrhizal fungi (Glomeromycota). Mycorrhiza 2013, 23, 515-531. [CrossRef] [PubMed]

47. Anderson, M.J. Distance-based tests for homogeneity of multivariate dispersions. Biometrics 2006, 62, $245-253$. [CrossRef] [PubMed]

48. Oksanen, J.; Blanchet, F.G.; Kindt, R.; Legendre, P.; Minchin, P.R.; O’Hara, R.B.; Simpson, G.L.; Solymos, P.; Stevens, M.H.H.; Wagner, H. Vegan: Community Ecology Package. R Package Version 3.2.1. 2012. Available online: http://vegan.r-forge.r-project.org/ (accessed on 11 July 2016).

49. Oksanen, J. Multivariate Analysis of Ecological Communities in R: Vegan Tutorial. 2011. Available online: http://cc.oulu.fi/ \{\}jarioksa/opetus/metodi/vegantutor.pdf (accessed on 22 July 2016). 
50. Hempel, S.; Renker, C.; Buscot, F. Differences in the species composition of arbuscular mycorrhizal fungi in spore, root and soil communities in a grassland ecosystem. Environ. Microbiol. 2007, 9, 1930-1938. [CrossRef] [PubMed]

51. Martínez-García, L.B.; Armas, C.; Miranda, J.D.D.; Padilla, F.M.; Pugnaire, F.I. Shrubs influence arbuscular mycorrhizal fungi communities in a semi-arid environment. Soil Biol. Biochem. 2011, 43, 682-689. [CrossRef]

52. Liu, Y.J.; He, L.; An, L.Z.; Helgason, T.; Feng, H.Y. Arbuscular mycorrhizal dynamics in a chronosequence of Caragana korshinskii plantations. FEMS Microbiol. Ecol. 2009, 67, 81-82. [CrossRef]

53. Hontoria, C.; García-González, I.; Quemada, M.; Roldán, A.; Alguacil, M.M. The cover crop determines the AMF community composition in soil and in roots of maize after a ten-year continuous crop rotation. Sci. Total Environ. 2019, 660, 913-922. [CrossRef]

54. Tamayo, E.; Gómez-Gallego, T.; Azcón-Aguilar, C.; Ferrol, N. Genome-wide analysis of copper, iron and zinc transporters in the arbuscular mycorrhizal fungus Rhizophagus irregularis. Front. Plant. Sci. 2014, 5, 547. [CrossRef]

55. Garcia, K.; Doidy, J.; Zimmermann, S.D.; Wipf, D.; Courty, P.-E. Take a trip through the plant and fungal transportome of mycorrhiza. Trends Plant. Sci. 2016, 21, 937-950. [CrossRef]

56. Chen, Y.L.; Zhang, X.; Ye, J.S.; Han, H.Y.; Wan, S.Q.; Chen, B.D. Six-year fertilization modifies the biodiversity of arbuscular mycorrhizal fungi in a temperate steppe in Inner Mongolia. Soil Biol. Biochem. 2014, 69, 371-381. [CrossRef]

57. Bailey-Serres, J.; Voesenek, L.A.C.J. Flooding stress: Acclimations and genetic diversity. Annu. Rev. Plant. Biol. 2008, 59, 313-339. [CrossRef]

58. Šraj-Kržič, N.; Pongrac, P.; Klemenc, M.; Kladnik, A.; Regvar, M.; Gaberščik, A. Mycorrhizal colonisation in plants from intermittent aquatic habitats. Aquat. Bot. 2006, 85, 331-336. [CrossRef]

59. Chen, F.Q.; Xie, Z.Q. Ecophysiological response of two herbaceous species to flooding. IEEE 2011, 4260-4263.

60. Alguacil, M.M.; Torres, M.P.; Torrecillas, E.; Diaz, G.; Roldán, A. Plant type differently promote the arbuscular mycorrhizal fungi biodiversity in the rhizosphere after revegetation of a degraded, semiarid land. Soil Biol. Biochem. 2011, 43, 167-173. [CrossRef]

61. Torrecillas, E.; Alguacil, M.M.; Roldán, A. Host preferences of arbuscular mycorrhizal fungi colonizing annual herbaceous plant species in semiarid Mediterranean prairies. Appl. Environ. Microb. 2012, 78, 6180-6186. [CrossRef] [PubMed]

62. Alguacil, M.M.; Lumini, E.; Roldán, A.; Salinas-García, J.R.; Bonfante, P.; Bianciotto, V. The impact of tillage practices on arbuscular mycorrhizal fungal diversity in subtropical crops. Ecol. Appl. 2008, 18, 527-536. [CrossRef] [PubMed]

63. Oehl, F.; Laczko, E.; Bogenrieder, A.; Stahr, K.; Bösch, R.; van der Heijden, M. Soil type and land use intensity determine the composition of arbuscular mycorrhizal fungal communities. Soil Biol. Biochem. 2010, 42, 724-738. [CrossRef]

64. Stürmer, S.L.; Siqueira, J.O. Species richness and spore abundance of arbuscular mycorrhizal fungi across distinct land uses in Western Brazilian Amazon. Mycorrhiza 2011, 21, 255-267. [CrossRef]

65. González-Cortés, J.C.; Vega-Fraga, M.; Varela-Fregoso, L.; Martínez-Trujillo, M.; Carreón-Abud, Y.; Gavito, M.E. Arbuscular mycorrhizal fungal (AMF) communities and land use change: The conversion of temperate forests to avocado plantations and maize fields in central Mexico. Fungal Ecol. 2012, 5, 16-23. [CrossRef]

66. Jefwa, J.M.; Okoth, S.; Wachira, P.; Karanja, N.; Kahindi, J.; Njuguini, S.; Ichami, S.; Mung'atu, J.; Okoth, P.; Huising, J. Impact of land use types and farming practices on occurrence of arbuscular mycorrhizal fungi (AMF) Taita-Taveta district in Kenya. Agr. Ecosyst. Environ. 2012, 157, 32-39. [CrossRef]

67. Moora, M.; Davison, J.; Öpik, M.; Metsis, M.; Saks, Ü.; Jairus, T.; Vasar, M.; Zobel, M. Anthropogenic land use shapes the com position and phylogenetic structure of soil arbuscular mycorrhizal fungal communities. FEMS Microbiol. Ecol. 2014, 903, 609-621. [CrossRef]

68. Ciccolini, V.; Bonari, E.; Pellegrino, E. Land-use intensity and soil properties shape the composition of fungal communities in Mediterranean peaty soils drained for agricultural purposes. Biol. Fertil. Soils 2015, 51, 719-731. [CrossRef]

69. Jansa, J.; Erb, A.; Oberholzer, H.R.; Smilauer, P.; Egli, S. Soil and geography are more important determinants of indigenous arbuscular mycorrhizal communities than management practices in Swiss agricultural soils. Mol. Ecol. 2014, 23, 2118-2135. [CrossRef] [PubMed] 
70. Pellegrino, E.; Bosco, S.; Ciccolini, V.; Pistocchi, C.; Sabbatini, T.; Silvestri, N.; Bonari, E. Agricultural abandonment in Mediterranean reclaimed peaty soils: Long-term effects on soil chemical properties, arbuscular mycorrhizas and $\mathrm{CO}_{2}$ flux. Agric. Ecosyst. Environ. 2014, 199, 164-175. [CrossRef]

71. Titus, J.H.; Lepš, J. The response of arbuscular mycorrhizae to fertilization, mowing, and removal of dominant species in a diverse oligotrophic wet meadow. Am. J. Bot. 2000, 87, 392-401. [CrossRef] [PubMed]

72. Barto, E.K.; Rillig, M.C. Does herbivory really suppress mycorrhiza? A meta-analysis. J. Ecol. 2010, 98, 745-753. [CrossRef]

73. Jansa, J.; Mozafar, A.; Anken, T.; Ruh, R.; Sanders, I.; Frossard, E. Diversity and structure of AMF communities as affected by tillage in a temperate soil. Mycorrhiza 2002, 12, 225-234.

74. Öpik, M.; Moora, M.; Liira, J.; Zobel, M. Composition of root-colonizing arbuscular mycorrhizal fungal communities in different ecosystems around the globe. J. Ecol. 2006, 94, 778-790. [CrossRef]

75. Rosendahl, S.; Matzen, H.B. Genetic structure of arbuscular mycorrhizal populations in fallow and cultivated soils. New Phytol. 2008, 179, 1154-1161. [CrossRef]

76. Landis, F.C.; Gargas, A.; Givnish, T.J. Relationships among arbuscular mycorrhizal fungi, vascular plants and environmental conditions in oak savannas. New Phytol. 2004, 164, 493-504. [CrossRef]

77. Tan, S.; Zhu, M.; Zhang, K.; Xu, H.; Zhang, Q. Effects of submergence on morpho-physiological characteristics and recovery of bermudagrass (Cynodon dactylon). Fresen. Environ. Bull. 2013, 22, 2533-2541.

78. Yang, H.; Yuan, Y.; Zhang, Q.; Tang, J.; Liu, Y.; Chen, X. Changes in soil organic carbon, total nitrogen, and abundance of arbuscular mycorrhizal fungi along a large-scale aridity gradient. Catena 2011, 87, 70-77. [CrossRef]

79. Stürmer, S.L.; Kemmelmeier, K.; Moreira, B.C.; Kasuya, M.C.M.; Pereira, G.M.D.; da Silva, K. Arbuscular mycorrhizal fungi (Glomeromycota) communities in tropical savannas of Roraima, Brazil. Mycol. Prog. 2018, 17, 1149-1159. [CrossRef]

80. Tchabi, A.; Coyne, D.; Hountondji, F.; Lawouin, L.; Wiemken, A.; Oehl, F. Arbuscular mycorrhizal fungal communities in sub-Saharan savannas of Benin, West Africa, as affected by agricultural land use intensity and ecological zone. Mycorrhiza 2008, 18, 181-195. [CrossRef] [PubMed]

81. Lu, X.; Lu, X.; Liao, Y. Effect of tillage treatment on the diversity of soil arbuscular mycorrhizal fungal and soil aggregate-associated carbon content. Front. Microbiol. 2018, 9, 2986. [CrossRef] [PubMed]

82. Wang, Z.T.; Li, T.; Wen, X.X.; Liu, Y.; Han, J.; Liao, Y.C.; DeBruyn, J.M. Fungal communities in rhizosphere soil under conservation tillage shift in response to plant growth. Front. Microbiol. 2017, 8, 1301. [CrossRef] [PubMed]

83. Liu, Y.J.; He, J.X.; Shi, G.X.; An, L.Z.; Öpik, M.; Feng, H.Y. Diverse communities of arbuscular mycorrhizal fungi inhabit sites with very high altitude in Tibet Plateau. FEMS Microbiol. Ecol. 2011, 78, 355-365. [CrossRef]

84. Dumbrell, A.J.; Ashton, P.D.; Aziz, N.; Feng, G.; Nelson, M.; Dytham, C.; Fitter, A.H.; Helgason, T. Distinct seasonal assemblages of arbuscular mycorrhizal fungi revealed by massively parallel pyrosequencing. New Phytol. 2011, 190, 794-804. [CrossRef]

85. Redecker, D. Specific PCR primers to identify arbuscular mycorrhizal fungi within colonized roots. Mycorrhiza 2000, 10, 73-80. [CrossRef]

86. Stockinger, H.; Krüger, M.; Schüssler, A. DNA barcoding of arbuscular mycorrhizal fungi. Neww Phytol. 2010, 187, 461-474. [CrossRef]

87. Gamper, H.A.; Walker, C.; Schussler, A. Diversispora celata sp. nov: Molecular ecology and phylotaxonomy of an inconspicuous arbuscular mycorrhizal fungus. New Phytol. 2009, 182, 495-506. [CrossRef]

88. Sýkorová, Z.; Ineichen, K.; Wiemken, A.; Redecker, D. The cultivation bias: Different communities of arbuscular mycorrhizal fungi detected in roots from the field, from bait plants transplanted to the field, and from a greenhouse trap experiment. Mycorrhiza 2007, 18, 1-14. [CrossRef] [PubMed]

89. Stockinger, H.; Walker, C.; Schüssler, A. 'Glomus intraradices DAOM197198' a model fungus in arbuscular mycorrhiza research, is not Glomus intraradices. New Phytol. 2009, 183, 1176-1187. [CrossRef] [PubMed]

90. Glenn, T.C. Field guide to next-generation DNA seqeuencers. Mol. Ecol. Resour. 2011, 11, 759-769. [CrossRef] [PubMed]

(C) 2019 by the authors. Licensee MDPI, Basel, Switzerland. This article is an open access article distributed under the terms and conditions of the Creative Commons Attribution (CC BY) license (http://creativecommons.org/licenses/by/4.0/). 